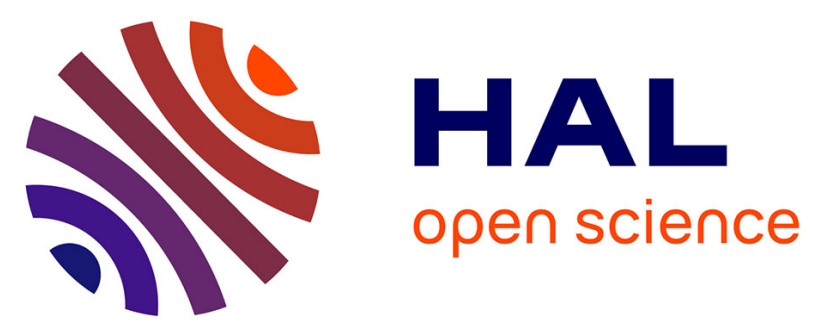

\title{
New insight into artifactual phenomena during in vitro toxicity assessment of engineered nanoparticles: Study of TNF- $\alpha$ adsorption on alumina oxide nanoparticle
}

Mélanie Pailleux, Delphine Boudard, Jérémie Pourchez, Valérie Forest, Philippe Grosseau, Michèle Cottier

\section{To cite this version:}

Mélanie Pailleux, Delphine Boudard, Jérémie Pourchez, Valérie Forest, Philippe Grosseau, et al.. New insight into artifactual phenomena during in vitro toxicity assessment of engineered nanoparticles: Study of TNF- $\alpha$ adsorption on alumina oxide nanoparticle. Toxicology in Vitro, 2013, 27, pp.10491056. 10.1016/j.tiv.2013.01.022 . hal-00799129

\section{HAL Id: hal-00799129 \\ https://hal.science/hal-00799129}

Submitted on 11 Mar 2013

HAL is a multi-disciplinary open access archive for the deposit and dissemination of scientific research documents, whether they are published or not. The documents may come from teaching and research institutions in France or abroad, or from public or private research centers.
L'archive ouverte pluridisciplinaire HAL, est destinée au dépôt et à la diffusion de documents scientifiques de niveau recherche, publiés ou non, émanant des établissements d'enseignement et de recherche français ou étrangers, des laboratoires publics ou privés. 
New insight into artifactual phenomena during in vitro toxicity assessment of engineered nanoparticles: study of TNF- $\alpha$ adsorption on alumina oxide nanoparticle

Mélanie Pailleux ${ }^{a, b}$, Delphine Boudard $^{\text {a,c,d,e }}$, Jérémie Pourchez $^{\text {a,f }}$, Valérie Forest ${ }^{\text {a,f }}$, Philippe Grosseau ${ }^{\mathrm{b}}$, Michèle Cottier ${ }^{\mathrm{a}, \mathrm{c}, \mathrm{d}, \mathrm{e}}$

${ }^{a}$ LINA, EA 4624, F-42023, Saint-Etienne, France

${ }^{\mathrm{b}}$ Ecole Nationale Supérieure des Mines de Saint-Etienne, SPIN-EMSE, CNRS :FRE3312,

LPMG, F-42023, Saint-Etienne, France

${ }^{\mathrm{c}}$ Université de Lyon, F-42023, Saint-Etienne, France

${ }^{\mathrm{d} U n i v e r s i t e ́ ~ J e a n ~ M o n n e t, ~ F a c u l t e ́ ~ d e ~ M e ́ d e c i n e, ~ F-42023, ~ S a i n t-E t i e n n e, ~ F r a n c e ~}$

${ }^{\mathrm{e}} \mathrm{CHU}$ de Saint-Etienne, F-42055, Saint-Etienne, France

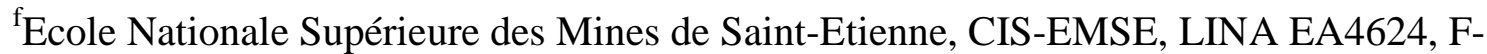
42023, Saint-Etienne, France

Running headline: Adsorption/degradation artifacts in toxicity study

Complete contact information:

Mélanie PAILLEUX

Centre SPIN

LPMG FRE 3312

École Nationale Supérieure des Mines de Saint-Etienne

158, Cours Fauriel - 42023 Saint-Etienne Cedex 2, FRANCE

E-mail : pailleux@emse.fr

Tel: (+33) 477499708 Fax: (+33) 477499694 


\section{ABSTRACT}

Biomolecules can be adsorbed on nanoparticles (NP) and degraded during in vitro toxicity assays. These artifactual phenomena could lead to misinterpretation of biological activity, such as false-negative results. To avoid possible underestimation of cytokine release after contact between NP and cells, we propose a methodology to account for these artifactual phenomena and lead to accurate measurements. We focused on the pro-inflammatory cytokine tumor necrosis factor TNF- $\alpha$. We studied well-characterized boehmite engineered NP [aluminum oxide hydroxide, $\mathrm{AlO}(\mathrm{OH})]$. The rate of TNF- $\alpha$ degradation and its adsorption (on boehmite and on the walls of wells) were determined in cell-free conditions by adding a known TNF- $\alpha$ concentration $(1500 \mathrm{pg} / \mathrm{ml})$ under various experimental conditions. After a 24$\mathrm{h}$ incubation, we quantified that $7 \mathrm{wt} \%$ of the initial TNF- $\alpha$ was degraded over time, $6 \mathrm{wt} \%$ adsorbed on the walls of 96-well plates, and $13 \mathrm{wt} \%$ adsorbed on the boehmite surface. Finally, boehmite NP were incubated with murine macrophages (RAW 264.7 cell line). The release of TNF- $\alpha$ was assessed for boehmite NP and the experimental data were corrected considering the artifactual phenomena, which accounted for about $20 \%-30 \%$ of the total.

Keywords: boehmite nanoparticles; toxicity; TNF- $\alpha$ adsorption; TNF- $\alpha$ degradation; correction curve 


\section{Introduction}

The importance of manufactured nanoparticles (NP) has steadily increased for 20 years. In 2015, the share of nanotechnology in the global economy will be about 1000 billion dollars (National Science Foundation, 2003). NP have applications in various fields such as automotive and multimedia industries (Chen et al., 2004; Murphy et al., 2005) and in cosmetics (Nohynek et al. 2007; Somasundaran and Krishnakumar, 1997) as well as in medicine. However, they may have effects on human health by inducing inflammation or oxidative stress. In particular, boehmite NP [aluminum oxide hydroxide, $\mathrm{AlO}(\mathrm{OH})]$ are used in a wide range of industrial applications and in many commercial products such as abrasive materials, catalysts, substrates for electronic circuits, and refractory materials; additionally, they are used as vectors in vaccines, replacing conventional adjuvants (Singh et al., 2007). Therefore, due to high potential exposures to boehmite NP, particularly in workplace environments, this type of nanomaterial represents an interesting model for biological activity assessments.

Although some toxicological evaluations have already been carried out, the potential impact on health of boehmite is not yet completely characterized. It has been shown during in vitro experiments using RAW 264.7 (murine monocyte/macrophage-like) and A549 (human lung cancer) cell lines that boehmite can induce inflammation (interleukin [IL]-8 production) and cytotoxicity (lactate dehydrogenase [LDH] release) (Kuhlbusch et al., 2009). As a result, boehmite could be considered to carry a potential health risk.

Recent papers clearly show that physicochemical properties should be taken into account in nanotoxicological studies (Boczkowski et al., 2010). Especially for in vitro assays, the possible interference between NP and either the medium compounds (assay reagents) or the detection systems (Geys et al., 2010; Horie et al., 2009; Kroll et al., 2009; MonteiroRiviere et al., 2009) should be carefully considered as well as the role of serum addition on 
dispersion and adsorption at the particle surface (Murdock et al., 2008) should be carefully considered. Moreover, some studies also suggest possible biases in the evaluation of the biological toxicity, particularly when the release of cytokines is assessed (Val, 2009). Indeed, the cytokines can be adsorbed at the surface of the NP, resulting in an underestimation of the quantity released (Akhtar et al., 2010; Cedervall et al., 2007; Val, 2009).

Cedervall et al. (2007) introduced an approach that identifies proteins on NP $(N$ isopropylacrylamide-co- $N$-tert-butylacrylamide) and the exchange with plasma proteins (human serum albumin). Val (2009) measured the capacity of titanium dioxide and carbon black NP to adsorb different pro-inflammatory cytokines, including IL-6, granulocyte monocyte colony-stimulating factor (GM-CSF), and tumor necrosis factor TNF- $\alpha$. Using different types of particulate matters and placing them in contact with standard IL-8 in a cellfree system, Akhtar et al. (2010) showed that particles exhibited differential IL-8 adsorption capacities depending on their physicochemical properties. These results tend to lead to the same conclusions: protein or cytokine adsorption on NP depends on NP surface characteristics and size; furthermore, the nature of the biomolecules adsorbed on the NP will affect the biological toxicity.

Additionally, Turci et al. (2010) used a new set of complementary techniques to characterize and compare the adsorption of different proteins on silica NP. The proteins studied were bovine serum albumin, hen egg lysozyme, bovine pancreatic ribonuclease A, and bovine lactoperoxidase. Although adsorption was influenced by the net protein charge, the surface charge distribution of proteins determined the affinity for the solid support (silica NP) and the stability of adsorption of proteins on silica NP.

Finally, Xia et al. (2010), using predictive models, described the kinetics of the protein corona formation. They used a biological surface adsorption index (BSAI) to characterize the adsorption properties of NP by quantifying the competitive adsorption of a set of small 
molecule probes onto NP by mimicking the molecular interactions of the NP with proteins. By these means, the molecular interactions of NP with proteins could be characterized by the BSAI nanodescriptors, which govern the adsorption affinity and selectivity of biomolecules onto the surfaces of nanomaterials in the corona-formation processes. These results were used to determine if the findings obtained for biological activity were correct or if they represented a false-negative result due to an artifact such as adsorption on NP.

The objectives of the present study were to highlight artifacts that could occur during in vitro toxicity assessments, especially in $\mathrm{TNF}-\alpha$ measurement, and to propose a methodology to quantify them in order to correct a possible underestimation of the TNF- $\alpha$ release. The TNF- $\alpha$ was chosen because inflammation can potentially be triggered by NP and the assessment of this cytokine is a very common test in nanotoxicology. This study, applied to the TNF- $\alpha$, rather represents a concept as the developed methodology can be extended to other kinds of molecules. Boehmite NP were incubated either in cell-free conditions or with a murine macrophage cell line (RAW 264.7). The experiments were conducted at two temperatures $\left(4{ }^{\circ} \mathrm{C}\right.$ and $\left.37{ }^{\circ} \mathrm{C}\right)$, with two types of support (glass flask or polystyrene 96 -well plates). We demonstrated that in addition to adsorption, TNF- $\alpha$ degradation also occurred. We finally proposed a correction applicable to boehmite, taking into account these two types of artifactual phenomena. The methodology for establishing the correction is easily transposable to other kinds of NP and biomolecules. 


\section{Material and Methods}

\section{Physicochemical characterization of NP}

Disperal ${ }^{\circledR}$ boehmite NP were purchased from Sasol (Germany).

The morphology of NP was analyzed using electron microscopy in the scanning electron microscopy (SEM) mode with a field-emission scanning electron microscope (JEOL JSM6500F) or in the transmission electron microscopy (TEM) mode with « $\mathrm{X} »$ transmission electron microscope.

The specific surface areas were determined by $\mathrm{N}_{2}$ adsorption at $77 \mathrm{~K}$ after out-gassing for $2 \mathrm{~h}$ at $200{ }^{\circ} \mathrm{C}$ (Micromeritics ASAP 2000), using the Brunauer-Emmet-Teller (BET) method.

NP densities were determined using a gas pycnometer (Micrometrics AccuPyc 1330) working under a helium atmosphere. Results are expressed as the means of 10 successive measurements on the same sample. For the zeta potential and size measurement, the boehmite suspension was fixed at $100 \mathrm{mg} / \mathrm{L}$ and prepared both in water and in complete Dulbecco's modified Eagle's medium (DMEM). Analyses were performed using a diffusion light scattering (DLS) device (ZetaSizer nano S, Malvern Instrument). X-ray diffraction (Siemens D5000 apparatus) experiments were performed at room temperature to examine the presence of crystalline phases. The crystallite size was calculated from the diffractograms obtained using the Scherrer relation (Topaz-4P software).

In vitro assays

$\underline{\text { Cell line and culture conditions }}$

The RAW 264.7 macrophage-like cell line, derived from mice, was provided by the ATCC Cell Biology Collection (Promochem LGC). Cells were cultured in DMEM (Gibco) 
complemented with $10 \%$ fetal calf serum (Gibco), $1 \%$ penicillin-streptomycin (penicillin $10,000 \mathrm{U} / \mathrm{ml}$, streptomycin $10 \mathrm{mg} / \mathrm{ml}$, Sigma) and incubated at $37{ }^{\circ} \mathrm{C}$ under a $5 \% \mathrm{CO}_{2}$ humidified atmosphere (Leclerc et al. 2010).

Boehmite (AlOOH) NP were resuspended in complete DMEM (DMEMc), vortexed for $30 \mathrm{~s}$ and then different concentrations were incubated with cells: 150, 300, 600, and 1200 $\mu \mathrm{g} / \mathrm{ml}$. Suspensions were freshly prepared just before experiments and discarded after each test series without any storage. We checked the hydrodynamic size of boehmite particles by DLS.

For each experiment, cells were prepared in 96-well plates $(100,000$ cells/well) in 25 $\mu 1$ of DMEMc. Seventy-five microliters of each boehmite suspension was added to the culture and then incubated for $24 \mathrm{~h}$ at $37^{\circ} \mathrm{C}$ in a $5 \% \mathrm{CO}_{2}$ atmosphere.

Three independent experiments were performed using four boehmite NP concentrations $(150,300,600$, and $1200 \mu \mathrm{g} / \mathrm{ml})$ and were tested for each of the following conditions: cells alone (negative control of toxicity), DQ 12 quartz (positive control of toxicity) (Bruch et al. 2004), and boehmite NP.

\section{LDH release}

The activity of the LDH released from cells with damaged membranes was assessed using the CytoTox-ONE ${ }^{\mathrm{TM}}$ Homogeneous Membrane Integrity Assay (Promega) according to the manufacturer's instructions. Detection was performed on a fluorometer (Fluoroskan Ascent, Thermolabsystems), using 530/590 nm excitation/emission wavelengths. The activity of the released LDH was reported in comparison to total cellular LDH (measured after control cell lysis) and was expressed as a percentage of the control.

\section{Pro-inflammatory TNF- $\alpha$ response}


After a 24-h incubation with NP, the release of TNF- $\alpha$ was assessed in the culture supernatant using a commercial enzyme-linked immunosorbent assay (ELISA) kit (Quantikine ${ }^{\circledR}$ Mouse TNF- $\alpha$ Immunoassay, R\&D Systems). The optical density of each well was determined according to the manufacturer's instructions by using a microplate reader (Multiskan RC, Thermolabsystems) set to $450 \mathrm{~nm}$. A standard curve was established and results were expressed in picograms of TNF- $\alpha$ per milliliter of supernatant.

\section{Assessment of artifactual phenomena}

\section{TNF- $\alpha$ degradation}

The TNF- $\alpha$ standard solution used for the assessment of adsorption and degradation phenomena was provided by the ELISA kit (Quantikine ${ }^{\circledR}$ Mouse TNF- $\alpha$ Immunoassay, R\&D Systems). The assays were performed in a cell-free environment. Since adsorption and degradation always occur simultaneously, to study these two phenomena independently glass flasks were used presenting a higher volume/surface ratio than wells of 96-wells plates (190 and $66 \mu 1 / \mathrm{cm}^{2}$ respectively). In these conditions, TNF- $\alpha$ adsorption becomes negligible over its degradation. Therefore experiments carried out in glass flasks allowed to limit adsorption and focus on degradation.

A defined amount of TNF- $\alpha(1500 \mathrm{pg} / \mathrm{ml})$ was suspended in DMEMc (without NP, in cell-free environment) in a glass flask at different temperatures: $4{ }^{\circ} \mathrm{C}$ (refrigerator) and $37{ }^{\circ} \mathrm{C}$ (incubator) for different times $(3,16,24$, and $48 \mathrm{~h})$. The $4{ }^{\circ} \mathrm{C}$ temperature corresponded to the TNF- $\alpha$ storage condition (to avoid any degradation phenomenon) and $37{ }^{\circ} \mathrm{C}$ corresponded to the in vitro experimental conditions. The difference between the results at $4{ }^{\circ} \mathrm{C}$ and $37{ }^{\circ} \mathrm{C}$ permitted to determine the quantity of degraded TNF- $\alpha$.

\section{$\underline{\text { TNF- } \alpha \text { adsorption on the support walls }}$}


A concentration of TNF- $\alpha(1500 \mathrm{pg} / \mathrm{ml})$ was added to DMEMc in 96-well plates, at 4 ${ }^{\circ} \mathrm{C}$ and $37^{\circ} \mathrm{C}$ for different durations $(3,16,24$, and $48 \mathrm{~h})$. The difference between the results in glass and in plastic allowed to determine the quantity of adsorbed TNF- $\alpha$ on the walls of wells.

\section{$\underline{\text { TNF- } \alpha \text { adsorption on boehmite }}$}

A concentration of TNF- $\alpha$ (1500 pg/ml, representing $75 \mathrm{pg}$ of TNF- $\alpha$ per well) was introduced with boehmite $(1200 \mu \mathrm{g}$, representing $12 \mu \mathrm{g}$ of NP per well) in DMEMc in 96well culture plates. After a 24-h contact, supernatants were collected, and the concentration of TNF- $\alpha$ was evaluated as previously described. The mass variation of TNF- $\alpha$ was then calculated.

\section{$\underline{\text { Adsorption isotherms of TNF- } \alpha}$}

Different TNF- $\alpha$ /boehmite weight ratios were established $(0.78,1.56,3.13$, and 6.25$)$ by adding varying amounts of TNF- $\alpha$ to cell cultures. Contact lasted for $1,3,16$, and $24 \mathrm{~h}$ at $37{ }^{\circ} \mathrm{C}$ in DMEMc in 96-well culture plates to determine the kinetics of TNF- $\alpha$ adsorption on boehmite. For each condition, the residual TNF- $\alpha$ was measured using the same ELISA procedure as previously described. For each ratio, the mass of adsorbed TNF- $\alpha$ was determined with regard to the duration of contact. It was estimated as the difference between the initial and residual concentrations of TNF- $\alpha$ in the supernatant, taking care to subtract degraded TNF- $\alpha$ as previously determined. When the adsorbed TNF- $\alpha$ reached a maximal level, the curve describing the mass of adsorbed TNF- $\alpha$, depending on the mass of residual TNF- $\alpha$, could be drawn. It represented the isotherm curve at the thermodynamic equilibrium, and it allowed correction of the results for the amount of TNF- $\alpha$ degraded and adsorbed on well walls and NP. 
Statistical analysis

Analysis and graphics were performed on Prism 5.0 software (GraphPad, San Diego, CA). Significance was established with ANOVA test $(p<0.05)$. 


\section{Results}

Physicochemical characterization of boehmite NP

$\underline{\text { Specific surface area, density, electron microscopy, and X-ray diffraction }}$

Boehmite is made of spherical particles. Although some particles exhibit a diameter of about $50 \mu \mathrm{m}$, the major part is much smaller (from 1 to $10 \mu \mathrm{m}$ in diameter). Small elements like platelets of around $20 \mathrm{~nm}$ can be observed by SEM (Figure 1).

The specific surface area, $S_{\mathrm{BET}}$, was measured as $157 \mathrm{~m}^{2} / \mathrm{g}$. The density, $\rho_{\mathrm{pp}}$, was determined to be $3.28 \mathrm{~g} / \mathrm{cm}^{3}$ by using the helium pycnometer. Using these data and Equation 1, we determined a primary particle diameter $\left(d_{\mathrm{pp}}\right)$ of $11.7 \mathrm{~nm}$, assuming a spherical shape of boehmite nanoparticles as confirmed by electron microscopy observation (Figure 1).

$$
d_{\mathrm{pp}}=\frac{6}{\rho_{\mathrm{pp}} \times S_{\mathrm{BET}}}
$$

where $d_{\mathrm{pp}}$ is expressed in micrometers, $\rho_{\mathrm{pp}}$ in grams per cubic centimeters, and $S_{\mathrm{BET}}$ in squared meters per gram.

The position of X-ray diffraction peaks was in agreement with the data reported for boehmite crystalline phase (JCPDS $\left.\mathrm{n}^{\circ} 21-1307\right)$. The broad diffraction lines revealed a crystallite size of $10 \pm 0.1 \mathrm{~nm}$ according to the Scherrer relation (Figure 2). This size was in perfect accordance with electron microscopy data.

\section{$\underline{\text { Particle size and zeta potential measurement }}$}

DLS assays (Figure 3) clearly showed that aggregation of the NP occurred in water and increased with $\mathrm{pH}$. At $\mathrm{pH} 3.5$, a narrow particle-size distribution was observed with a maximum at $50 \mathrm{~nm}$; at $\mathrm{pH} 6.9$ the maximum was located at $315 \mathrm{~nm}$; and finally at $\mathrm{pH} 9.4$, the particle size was $770 \mathrm{~nm}$. In DMEMc (pH 7.4) NP showed a broad particle-size distribution, with a maximum at $825 \mathrm{~nm}$. 
Thus, at a similar $\mathrm{pH}$, boehmite NP are more aggregated in DMEMc than in water (825 $\mathrm{nm}$ and $315 \mathrm{~nm}$, respectively).

Zeta potential measurement proved that NP have a positive surface charge until $\mathrm{pH} 9.5$ (the isoelectric point); beyond this value, NP are negatively charged. This result explained the rise of agglomeration observed with $\mathrm{pH}$. As a matter of fact, the more the $\mathrm{pH}$ was near the isoelectric point, the more the NP were agglomerated.

In vitro toxicity assessment

\section{$\underline{\mathrm{LDH} \text { release }}$}

Cells incubated for $24 \mathrm{~h}$ with boehmite NP released the same level of LDH as the negative control (cells tested alone, without NP) and no dose-dependent effect was observed (Figure 4A).

The positive control of toxicity (DQ12 quartz) exhibited a level of released LDH that was significantly higher and dose dependent (34\% of released $\mathrm{LDH}$ for $1200 \mu \mathrm{g} / \mathrm{ml}$ of boehmite).

\section{Pro-inflammatory TNF- $\alpha$ response}

The amount of TNF- $\alpha$ released by cells alone was quite negligible $(250 \mathrm{pg} / \mathrm{ml})$ (Figure 4B). No significant difference from the control group was observed when boehmite was incubated with macrophages for $24 \mathrm{~h}$ (300 $\mathrm{pg} / \mathrm{ml}$ of TNF- $\alpha$ produced). However, incubation with the DQ 12 quartz positive control induced a high TNF- $\alpha$ release (800 to $1000 \mathrm{pg} / \mathrm{ml}$ ) which was clearly dose-dependent. 
The experiment in the glass flask at $4^{\circ} \mathrm{C}$ clearly showed no significant adsorption and no degradation phenomena (Figure 5). For the same experimental conditions at $37^{\circ} \mathrm{C}$, we assumed that the observed mass change of TNF- $\alpha$ was due only to the degradation phenomenon ( $\Delta \mathrm{m}$ TNF- $\alpha$ of $6.5 \mathrm{wt} \%$ after $24 \mathrm{~h})$. Finally, the amount of TNF- $\alpha$ degraded in DMEMc was dependent on the duration of the experiment and the temperature, and we approximated the rate of TNF- $\alpha$ degradation at $0.12 \mathrm{pg} / \mathrm{h}$ at $37{ }^{\circ} \mathrm{C}$ in DMEMc.

$\underline{\text { TNF- } \alpha \text { adsorption on the walls of the wells }}$

After $24-\mathrm{h}$ contact at $37^{\circ} \mathrm{C}$ in DMEMc without boehmite, $11.6 \mathrm{wt} \%$ loss of TNF- $\alpha$ was observed in polystyrene wells. Under these conditions, both TNF- $\alpha$ degradation and adsorption on the walls of the well occurred. However, loss only reached $6.5 \mathrm{wt} \%$ in the glass flask in which only degradation occurred, given the very low surface to volume ratio of the flask. Thus, we demonstrated significant TNF- $\alpha$ adsorption on the walls of wells in which we did the assays. This adsorption was calculated by the difference between experiments in wells and in the glass flask.

$\underline{\text { TNF- } \alpha \text { adsorption on boehmite }}$

A significant increase in TNF- $\alpha$ mass loss $(\Delta \mathrm{m}$ TNF- $\alpha)$ was observed after a $24-\mathrm{h}$ incubation of cells with boehmite (24.8 wt\% versus $11.6 \mathrm{wt} \%$ without boehmite) (Figure 5). These results suggest that significant TNF- $\alpha$ adsorption on boehmite occurred. A saturation of TNF- $\alpha$ adsorption on boehmite can also be noticed as a plateau was reached (about 25\%).

\section{$\underline{\text { Adsorption isotherms of TNF- } \alpha}$}

The kinetics curve of adsorption revealed that the amount of TNF- $\alpha$ adsorbed on the boehmite surface reached a thermodynamic equilibrium at $24 \mathrm{~h}$, regardless of the boehmite to 
TNF- $\alpha$ weight ratio (Figure 6). Thus, the curve representing the adsorbed TNF- $\alpha$ based on the residual TNF- $\alpha$ could be drawn (i.e., the adsorption isotherm curve), after subtracting the amount of degraded TNF- $\alpha$, which was calculated based on the previously determined TNF- $\alpha$ degradation rate of $0.12 \mathrm{pg} / \mathrm{h}$.

Using the adsorption isotherm curve and knowing the amount of residual TNF- $\alpha$ in the supernatant, we could determine the amount of adsorbed TNF- $\alpha$. For example, for a weight dose of $1200 \mu \mathrm{g} / \mathrm{ml}$ of boehmite in contact with the macrophage cell line, the concentration of TNF- $\alpha$ released after $24 \mathrm{~h}$ in the supernatant was about $300 \mathrm{pg} / \mathrm{ml}$ (Figure 4); i.e., $1.25 \mathrm{pg}$ of TNF- $\alpha$ in solution per microgram of boehmite initially introduced. The adsorption isotherm (Figure 7) led us to estimate that if there was $1.25 \mathrm{pg}$ of TNF- $\alpha$ in the supernatant per microgram of boehmite, $0.2 \mathrm{pg}$ of TNF- $\alpha$ was adsorbed per microgram of boehmite. Since the mass of boehmite introduced per wells was $12 \mu \mathrm{g}$, we calculated that 2.4 pg of TNF- $\alpha$ would be adsorbed on boehmite. Therefore after a 24-h incubation for a weight dose of $1200 \mu \mathrm{g} / \mathrm{ml}$ of boehmite, we estimated $26 \%$ of $\Delta \mathrm{m}$ TNF- $\alpha$ artifacts, taking into account adsorption and degradation phenomena.

\section{$\underline{\text { Corrected data }}$}

Figure 8 represents our data after correction of TNF- $\alpha$ adsorption and degradation artifacts as previously determined. TNF- $\alpha$ degradation and adsorption on the walls of wells is constant (about 13\%), whereas TNF- $\alpha$ adsorption on boehmite NP must be calculated for each experimental condition as reported on Figure 8.

After correction of the artifacts, the TNF- $\alpha$ production was found to be higher than that of cells unexposed to NP even though the difference was not judged statistically significant (ANOVA test, $\mathrm{p}>0.05$ ). 


\section{Discussion}

There have been concerns in recent years about the effects of NP on health (Oberdorster et al., 2005). Many studies have described the pro-inflammatory effects of different NP, particularly in the respiratory system, which represents the main route of exposure (Oberdorster et al., 2005; Singh et al., 2007; Xia et al., 2006).

The binding of proteins to NP surfaces is a well-known phenomenon that is specific to the NP surface characteristics and also depends on the nature of the proteins. For instance, adsorption of TNF- $\alpha$ on carbon black and titanium dioxide NP has been reported, and the adsorption of other cytokines such as IL-6 and GM-CSF has also been observed (Val, 2009). Models describing the kinetics of the adsorption of the proteins on NP have been established (Dell'Orco et al., 2010; Xia et al., 2010). The main objective of the present work was to provide new insight on the possible artifacts of measures that could occur during in vitro toxicity assessments. We focused our attention on TNF- $\alpha$, evaluating its adsorption and degradation. We aimed to demonstrate that a correction could be established to avoid underestimating cytokine release in the presence of nanoparticles that might have a high adsorption capacity due to their huge surface area. Owing to a lack of data in the literature about TNF- $\alpha$ adsorption on nanoparticles, we selected boehmite to illustrate that the potential impact of artifacts associated with nanoparticles is not negligible. To that purpose, in vitro TNF- $\alpha$ measurements were performed in a cell-free environment or after contact with a macrophage cell line.

First, different techniques were used for physicochemical characterization to evaluate the size of primary particles. All techniques yielded the same conclusions: boehmite nanoparticle size is about $10 \mathrm{~nm}$, and the particles have a strong tendency to aggregate in suspension. The DLS technique was used to assess the state of NP aggregation in cell culture medium and in water, and the observations of different sized NP aggregates in cell culture 
medium were in agreement with literature reports (Limbach et al., 2005; Singh et al., 2007; $\mathrm{Xia}$ et al., 2006). However, the size of aggregates depended on the $\mathrm{pH}$ of the solution as measured by variations of the zeta potential (Turci et al., 2010). For boehmite NP, aggregation increased with the $\mathrm{pH}$.

Secondly, the pro-inflammatory effect of boehmite NP was evaluated after 24-h contact with macrophages. In a global manner, TNF- $\alpha$ production was limited (about 300 $\mathrm{pg} / \mathrm{ml}$ ) compared with the positive control for toxicity $(800-1000 \mathrm{pg} / \mathrm{ml})$.

In order to check the accuracy of our results and eliminate potential experimental biases, we investigated whether TNF- $\alpha$ degraded over time and whether it could be adsorbed at the surface of the NP and on the support. Indeed, adsorption caused a strong underestimation of the amount of TNF- $\alpha$ release as quantified by ELISA. To that purpose, we introduced a defined amount of TNF- $\alpha(1500 \mathrm{pg} / \mathrm{ml})$ in solution, in cell-free conditions with and without boehmite NP, and we quantified the amount of degraded and/or adsorbed TNF- $\alpha$. We were able to establish the following relationship:

$[\mathrm{TNF}-\alpha]_{\text {in the supernatant }}=[\mathrm{TNF}-\alpha]_{\text {produced by cells }}-[\mathrm{TNF}-\alpha]_{\text {adsorbed on }(\mathrm{NP}+\text { wells })}-[\mathrm{TNF}-\alpha]_{\text {degraded }}$ [2]

Each term of this equation was studied, and the disappearance of TNF- $\alpha$ over time and as a factor of temperature was observed. When $75 \mathrm{pg}$ of TNF- $\alpha$ was added to $12 \mu \mathrm{g}$ of NP in cell culture medium, the mass of TNF- $\alpha$ measured after $24 \mathrm{~h}$ at $37{ }^{\circ} \mathrm{C}$ was only $58 \mathrm{pg}$, representing a loss of $26 \mathrm{wt} \%$. We specifically established that $7 \mathrm{wt} \%$ TNF- $\alpha$ was degraded, 6 wt $\%$ TNF- $\alpha$ was adsorbed on walls of wells, and $13 \mathrm{wt} \%$ TNF- $\alpha$ was adsorbed on the boehmite NP surface. 
However, results may depend on the biomolecules and the type of NP studied. For instance, Val (2009) showed that IL-6 was not adsorbed on carbon black and titanium dioxide, but in contrast GM-CSF and TNF- $\alpha$ were completely adsorbed by carbon black and partially by titanium dioxide (60\% for GM-CSF and $26 \%$ for TNF- $\alpha$ ). Our results are in agreement with this study. We observed an adsorption of TNF- $\alpha$ on boehmite NP and on the support of the assays, but we also demonstrated disappearance of TNF- $\alpha$ due to degradation.

The interactions between LDH and NP have not been investigated in this study as it was beyond the scope of the present paper. The aim of this work was to highlight the fact that artifacts can occur in common nanotoxicological tests and to avoid misinterpretation of the results a methodology could be developed to take them into consideration and correct them. We did not mean to be exhaustive and we chose to illustrate this concept with a very frequently assessed cytokine: TNF- $\alpha$. Of course, this concept can be extended to other molecules but generalities cannot be drawn, the corrections to bring are highly dependent on the nature of the NP, the materials, the protocols... as already mentioned (Val, 2009). Actually, it is very likely that the same phenomenon as described for TNF- $\alpha$ occur for LDH and these artifacts must be measured too for a comprehensive study. Furthermore, artifacts in the LDH assessment could explain the slight decrease in the amount of released LDH by cells exposed to boehmite NP compared to that of control, unexposed cells. However, assessing LDH artifacts is currently impossible because of technical limitations. We were able to study TNF- $\alpha$ artifacts because a standard TNF- $\alpha$ solution was provided in the detection kit. Therefore by adding a known amount of TNF- $\alpha$ in various experimental conditions we could easily follow a variation of its mass and deduce from this $\Delta \mathrm{m}$ the amount of degradation and/or adsorption of this molecule. This method is clearly impossible to transpose to the LDH assay as no LDH standard solution is provided in the detection kit (which would be the best standard) nor is commercially available. We can find LDH extracted and purified from human 
or different species but to the best of our knowledge no murine LDH was found. And it will be a non sense to compare things which are from different species and therefore are not comparable. The possibility to recover LDH from lyzed cells was also considered but in this case cell lysats would also contain various biomolecules which would interfere with the kit reagents and induce other artifacts in the measures.

Keeping in mind the models describing the kinetics of the adsorption of the proteins on NP (Dell'Orco et al., 2010; Xia et al., 2010), we performed a kinetic study. Results allowed us to plot a corrective curve when the thermodynamic equilibrium was reached for different NP to TNF- $\alpha$, ratios which led us to establish a correction to avoid misinterpretation of TNF- $\alpha$ release in the presence of nanoparticles.

After such a quantitative evaluation of the artifacts the original data were corrected to take into account these biases and give more accurate results.

Biomolecule adsorption onto material surface (e.g., nanoparticles) occurs by multiple short-range interactions (H-bond, electrostatic, van der Waals or dispersive forces, hydrophobic effect) that are individually rather weak (a few $\mathrm{k}_{\mathrm{b}} \mathrm{T}$ or less), but additively they induce a significant adsorption energy. The classic view of Langmuir isotherms assumes that some interaction energy is reversibly available to create a biomolecule-material surface complex. The amount of adsorbed biomolecules is limited by the available area on a material's surface, thus the surface area of nanoparticles is doubtless a key parameter influencing the adsorption artifact in in vitro nanotoxicology experiments. Moreover, when the NP surface is functionalized or covered with a given biomolecule, its surface properties are changed, and this modifies the adsorption of other biomolecules remaining in solution. As a result, nonspecific adsorption of proteins such as bovine serum albumin or casein can be proposed to sterically "block" the material surface so as to prevent the unwanted adsorption of valuable and interesting biomolecule such as cytokines. Nevertheless, as the physicochemical 
features of a surface compose a key point to be taken into account in nanotoxicology studies, the saturation of nanoparticles' surfaces may strongly modify the biological activity compared to uncoated nanoparticles.

In conclusion, we have studied the physicochemical characteristics of boehmite NP and their capacity to adsorb a specific biomolecule, TNF- $\alpha$, which is often assessed in in vitro toxicological studies. Results showed the existence of an adsorption process conjugated with degradation, leading to underestimation of the actual amount of TNF- $\alpha$ released during in vitro toxicity assays. To our knowledge, this is the first study introducing a correction that takes artifacts into account and is adaptable to other types of biomolecules and NP.

\section{Conflict of interest statement}

The authors report no conflicts of interest. 


\section{References}

Akhtar, U.S., McWhinney, R.D., Rastogi, N., Abbatt, J.P., Evans, G.J., Scott, J.A., 2010. Cytotoxic and proinflammatory effects of ambient and source-related particulate matter (PM) in relation to the production of reactive oxygen species (ROS) and cytokine adsorption by particles. Inhal. Toxicol. 22(Suppl. 2), 37-47.

Boczkowski, J., Hoet, P., 2010. What's new in nanotoxicology? Implications for public health from a brief review of the 2008 literature. Nanotoxicology, 4 1-14.

Bruch, J., Rehn, S., Rehn, B., Borm, P.J., Fubini, B., 2004. Variation of biological responses to different respirable quartz flours determined by a vector model. Int. J. Hyg. Environ. Health 207, 203-16.

Cedervall, T., Lynch, I., Lindman, S., Berggård, T., Thulin, E., Nilsson, H., Dawson, K.A., Linse, S., 2007. Understanding the nanoparticle-protein corona using methods to quantify exchange rates and affinities of proteins for nanoparticles. Proc. Natl. Acad. Sci. 104, 2050-2055.

Chen, W., Zhang, J., Joly, A., 2004. Optical properties and potential applications of doped semiconductor nanoparticles. J. Nanosci. Nanotechnol. 4, 919-947.

Dell'Orco, D., Lundqvist, M., Oslakovic, C., Cedervall, T., Linse, S., 2010. Modeling the time evolution of the nanoparticle-protein corona in a body fluid. PLoS One 5, e10949.

Geys, J., Nemery, B., Hoet, P.H.M., 2010. Assay conditions can influence the outcome of cytotoxicity tests of nanomaterials: Better assay characterization is needed to compare studies. Toxicol. in Vitro 24, 620-629.

Horie, M., Nishio, K., Fujita, K., Endoh, S., Miyauchi, A., Saito, Y., Iwahashi, H., Yamamoto, K., Murayama, H., Nakano, H., Nanashima, N., Niki, E., Yoshida, Y., 2009. Protein adsorption of ultrafine metal oxide and its influence on cytotoxicity 
toward cultured cells. Chem. Res. Toxicol. 22, 543-553.

Kroll, A., Pillukat, M.H., Hahn, D., Schnekenburger, J., 2009. Current in vitro methods in nanoparticle risk assessment: Limitations and challenges. Eur. J. Pharm. Biopharm. $72,370-377$.

Kuhlbusch, T.A.J., Krug, H.F., Nau, K., Nau, K., Krug, H.F., Kusche, O., Dickerhof, M., Quendt, C., Fleischer, T., Mülhopt, S., Paur, H.R., 2009. NanoCare: Health related aspects of nanomaterials: Final scientific report, ed Dechema, Frankfurt.

Leclerc, L., Boudard, D., Pourchez, J., Forest, V., Sabido, O., Bin, V., Palle, S., Grosseau, P., Bernache, D., Cottier, M., 2010. Quantification of microsized fluorescent particles phagocytosis to a better knowledge of toxicity mechanisms. Inhal. Toxicol. 22, 10911100

Limbach, L., Li, Y., Grass, R.N., Brunner, T.J., Hintermann, M.A., Muller, M., Gunther, D., Stark, W.J., 2005. Oxide nanoparticle uptake in human lung fibroblasts: Effects of particle size, agglomeration, and diffusion at low concentrations. Environ. Sci. Technol. 39, 9370-9376.

Monteiro-Riviere, N., Inman, A., Zhang, L., 2009. Limitations and relative utility of screening assays to assess engineered nanoparticle toxicity in a human cell line. Toxicol. Appl. Pharmacol. 234, 222-235.

Murdock, R., Braydich-Stolle, L., Schrand, A.M., Schlager, J.J., Hussain, S.M., 2008. Characterization of nanomaterial dispersion in solution prior to In vitro exposure using dynamic light scattering technique. Toxicol. Sci. 101, 239-253.

Murphy, C., Sau, T.K., Gole, A.M., Orendorff, C.J., Gao, J., Gou, L., Hunyadi, S.E., Li, T., 2005. Anisotropic metal nanoparticles: Synthesis, assembly, and optical applications. J. Phys. Chem. B 109, 13857-13870.

Nohynek, G., Lademann, J., Ribaud, C., Roberts, M.S., 2007. Grey goo on the skin? 
Nanotechnology, cosmetic and sunscreen safety. Crit. Rev. Toxicol. 37, 251-277.

National Science Foundation (NSF). 2003. "The future of National Nanotechnology Initiative, program announcement. Boston, Available online: http://www.nsf.gov/nano.

Oberdorster, G., Oberdorster, E., Oberdorster, J., 2005. Nanotoxicology: An emerging discipline evolving from studies of ultrafine particles. Environ. Health Perspect. 113, 823-839.

Singh, S., Shi, T., Duffin, R., Albrecht, C., van Berlo, D., Höhr, D., Fubini, B., Martra, G., Fenoglio, I., Borm, P.J., Schins, R.P., 2007. Endocytosis, oxidative stress and IL-8 expression in human lung epithelial cells upon treatment with fine and ultrafine $\mathrm{TiO} 2$ : Role of the specific surface area and of surface methylation of the particles. Toxicol. Appl. Pharmacol. 222, 141-151.

Somasundaran, P., Krishnakumar, S., 1997. Adsorption of surfactants and polymers at the solid-liquid interface. Colloids Surf. A: Physicochem. Eng. Asp. 123, 491-513.

Turci, F., Ghibaudi, E., Colonna, M., Boscolo, B., Fenoglio, I., Fubini, B., 2010. An integrated approach to the study of the interaction between proteins and nanoparticles. Langmuir 26, 8336-8346.

Val, S., 2009. Carbon black and titanium dioxide nanoparticles induce pro-inflammatory responses in bronchial epithelial cells: Need for multiparametric evaluation due to adsorption artifacts. Inhal. Toxicol. 21, 115-122.

Xia, T., Kovochich, M., Brant, J., Hotze, M., Sempf, J., Oberley, T., Sioutas, C., Yeh, J.I., Wiesner, M.R., Nel, A.E., 2006. Comparison of the abilities of ambient and manufactured nanoparticles to induce cellular toxicity according to an oxidative stress paradigm. Nano Lett. 6, 1794-1807.

Xia, X.R., Monteiro-Riviere, N.A., Riviere, J.E., 2010. An index for characterization of nanomaterials in biological systems. Nat. Nanotechnol. 5, 671-675. 


\section{FIGURES}

Fig. 1. (A) SEM and (B) TEM images of particles.
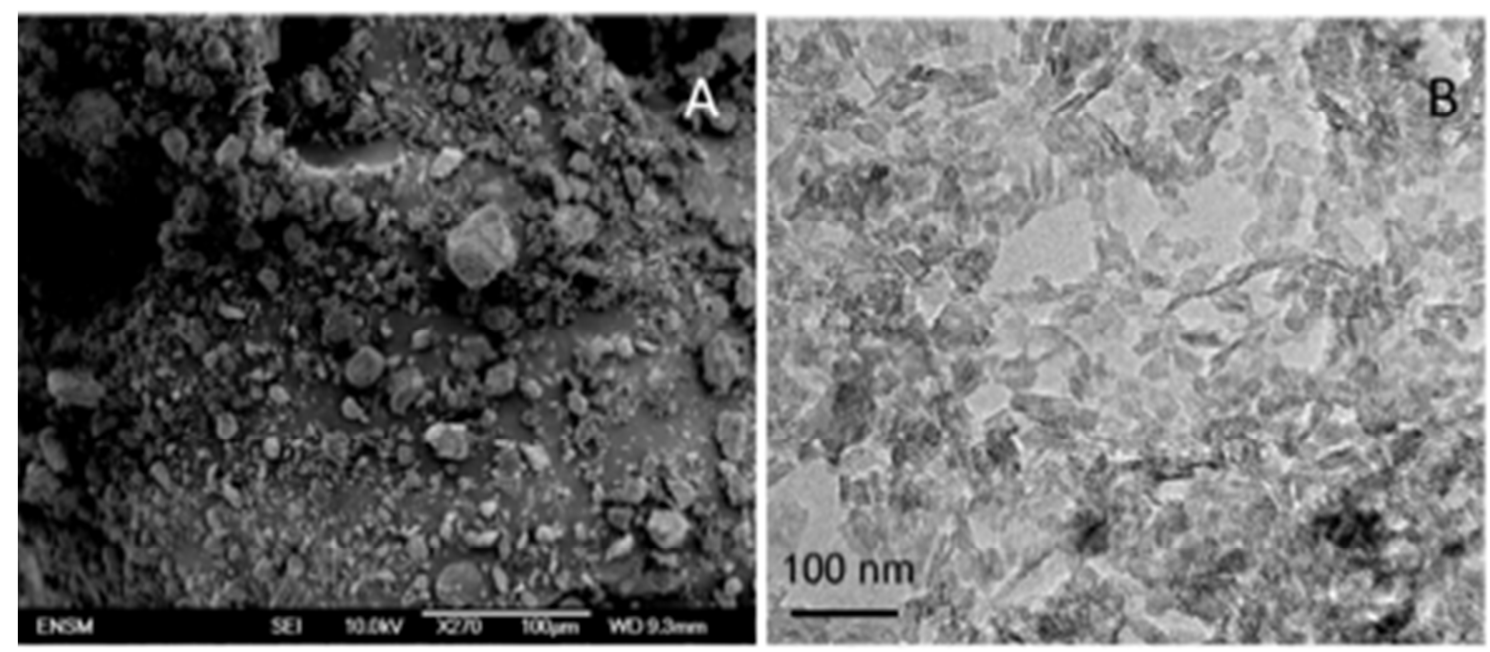

Fig. 2. Diffractogram of the boehmite NP.

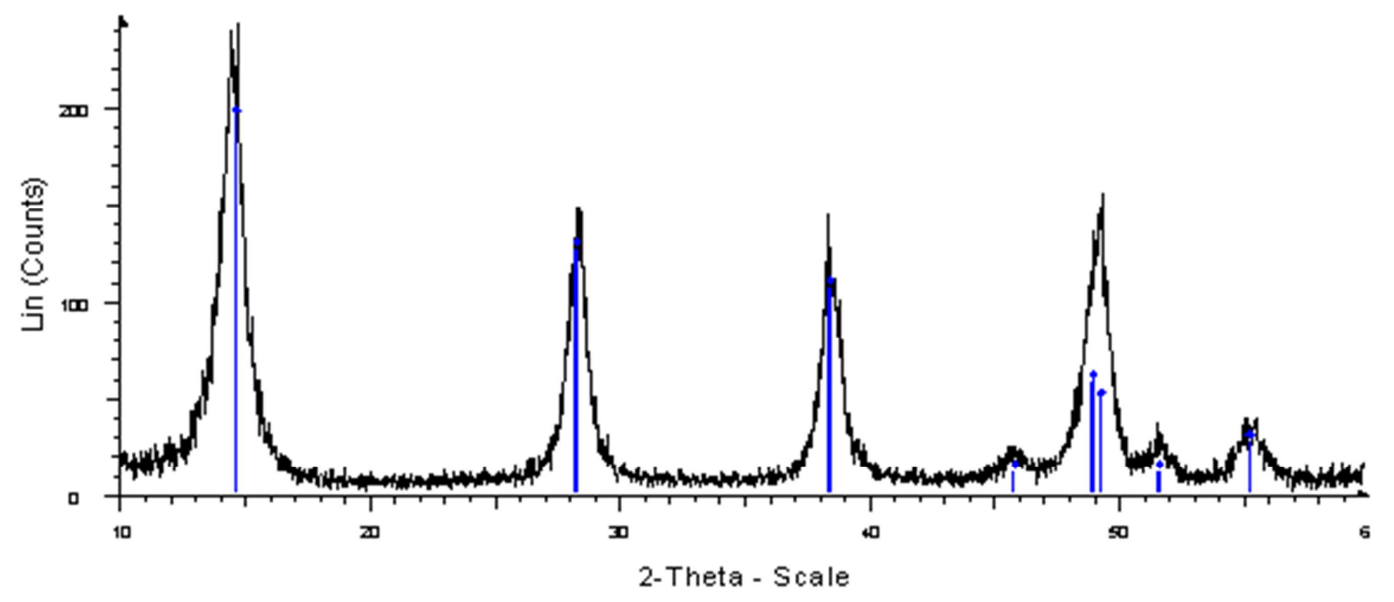

Fig. 3. Average diameter of particles depending on the $\mathrm{pH}$ in water and variation of zeta potential. 


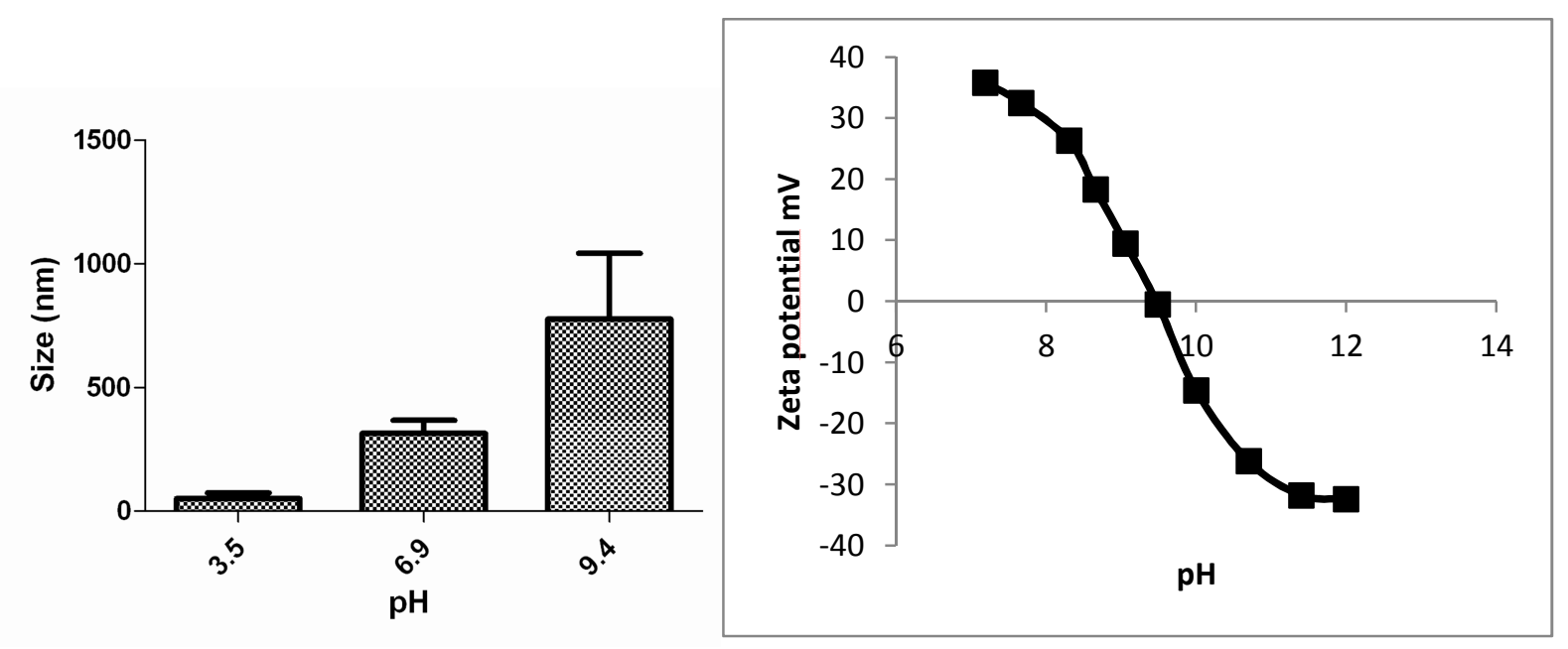

Fig. 4. Toxicity assessment. RAW 264.7 cells were incubated with boehmite NP for $24 \mathrm{~h}$, and (A) cell damage measured by the amount of $\mathrm{LDH}$ released and (B).the TNF- $\alpha$ production $(\mathrm{pg} / \mathrm{ml})$ were assessed. This production was compared to that of cells alone (negative control of toxicity) and to that of cells incubated with DQ12 quartz (positive control) $\left(n=3,{ }^{*} p<\right.$ $0.0001)$

A. 


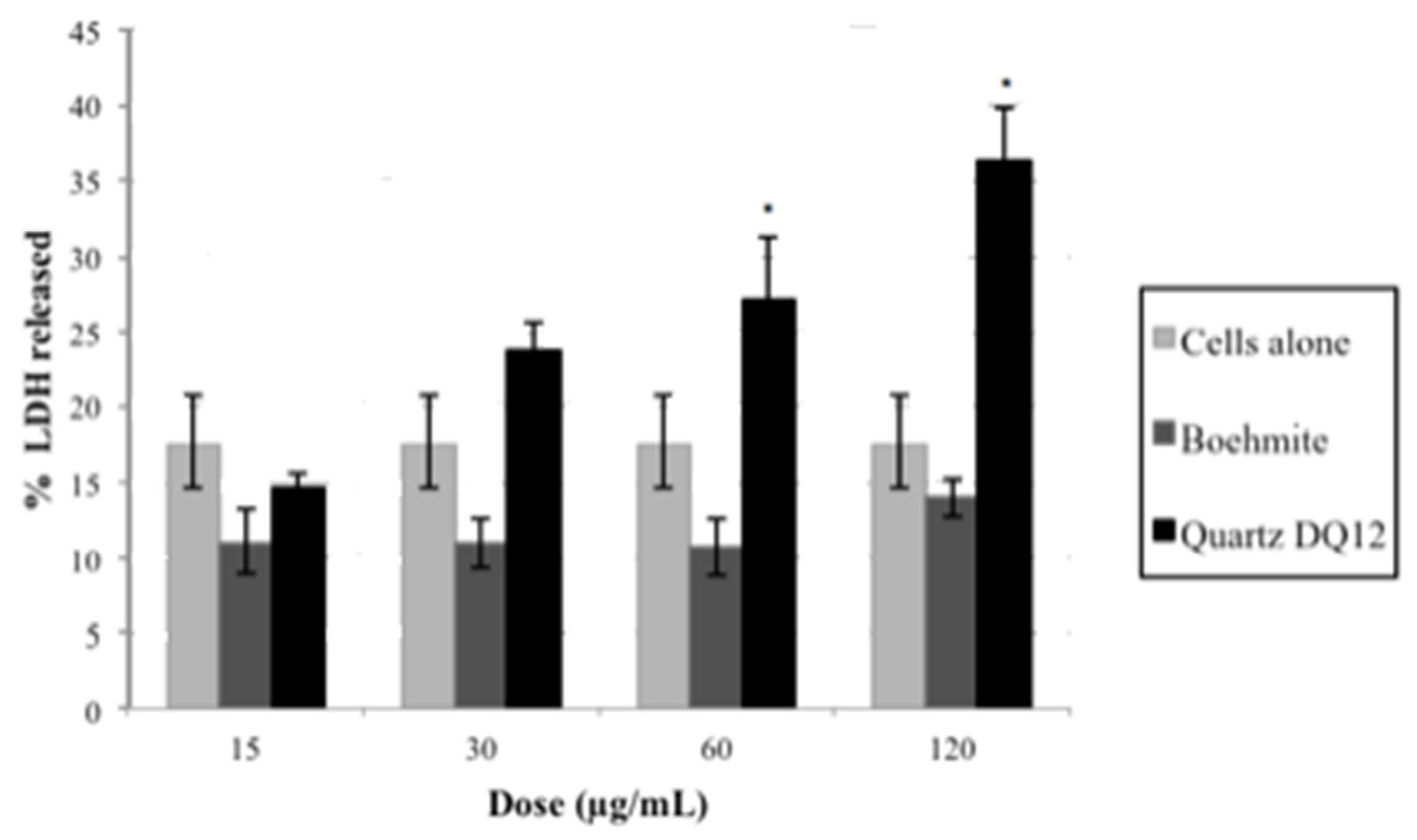

B.

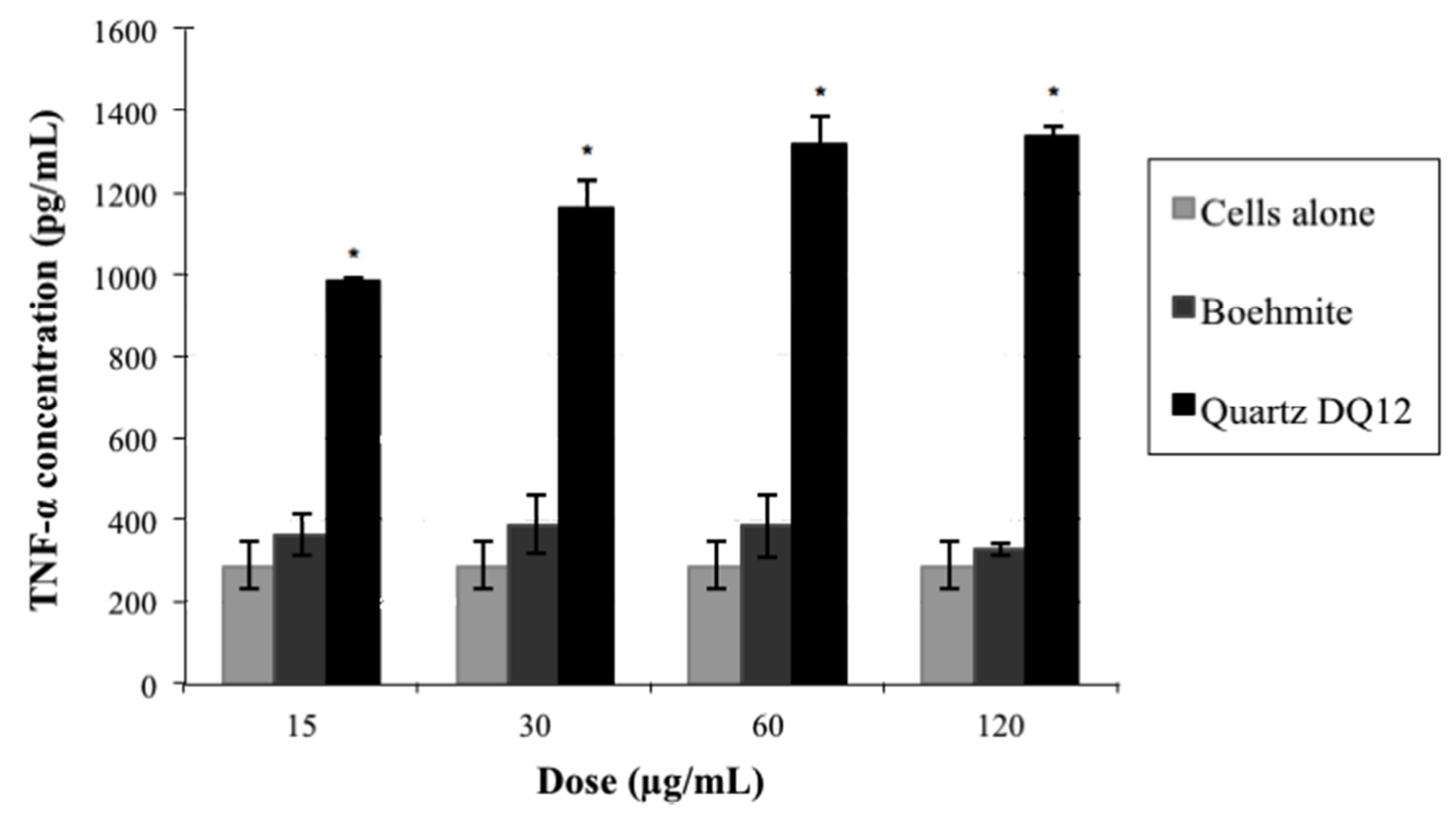

Fig. 5. Adsorption of TNF- $\alpha$ depending on the temperature $\left(4{ }^{\circ} \mathrm{C}\right.$ or $\left.37{ }^{\circ} \mathrm{C}\right)$, the duration of incubation $(3,16,24$, and $48 \mathrm{~h})$, the nature of the support (polystyrene or glass), and the presence of boehmite NP in cell-free conditions, TNF- $\alpha$ mass loss $(\Delta \mathrm{m}$ TNF- $\alpha)$. 


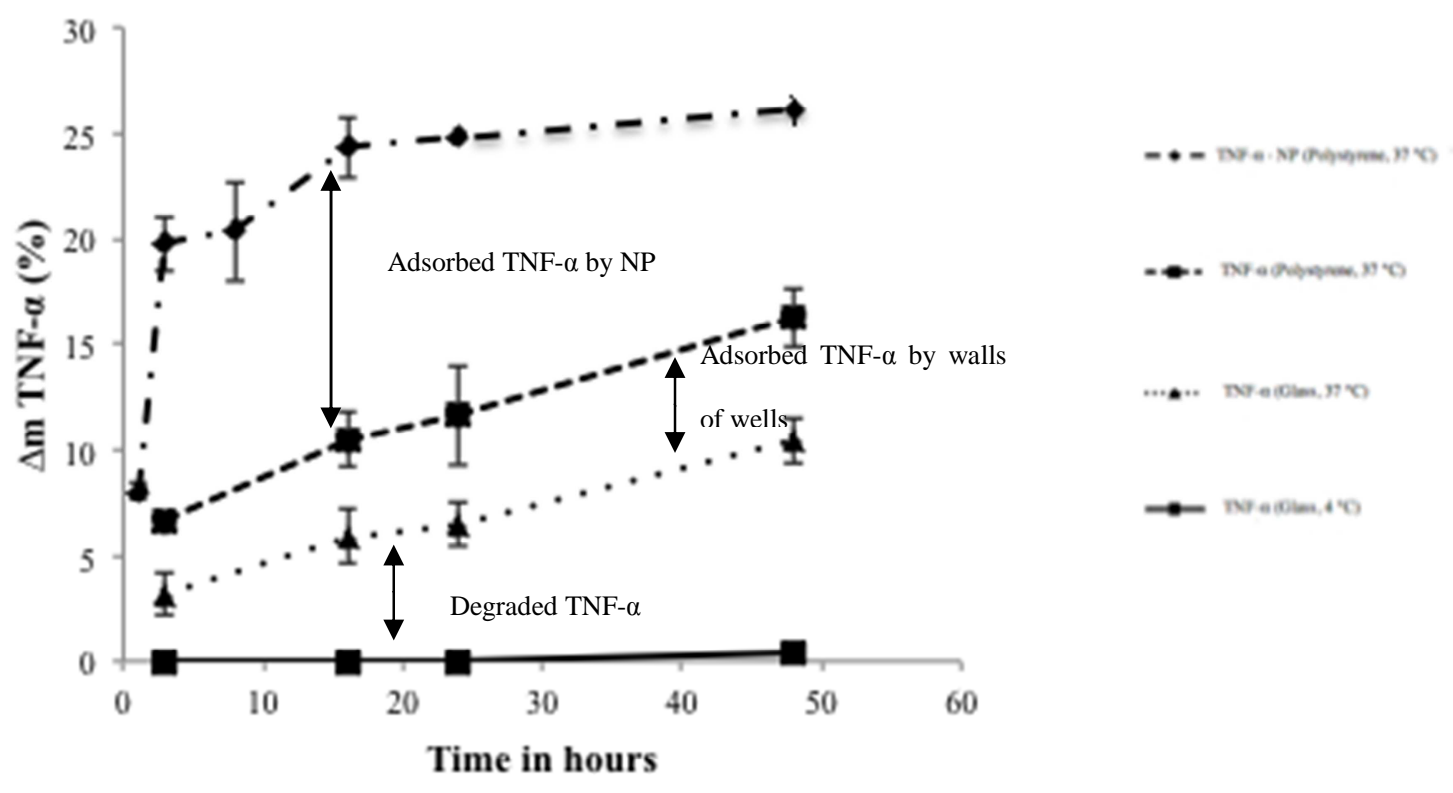

Fig. 6. Adsorption kinetics of different boehmite NP/TNF- $\alpha$ mass ratios $(0.78,1.56,3.13$, 6.25) for different times $(1,3,16$, and $24 \mathrm{~h})$.

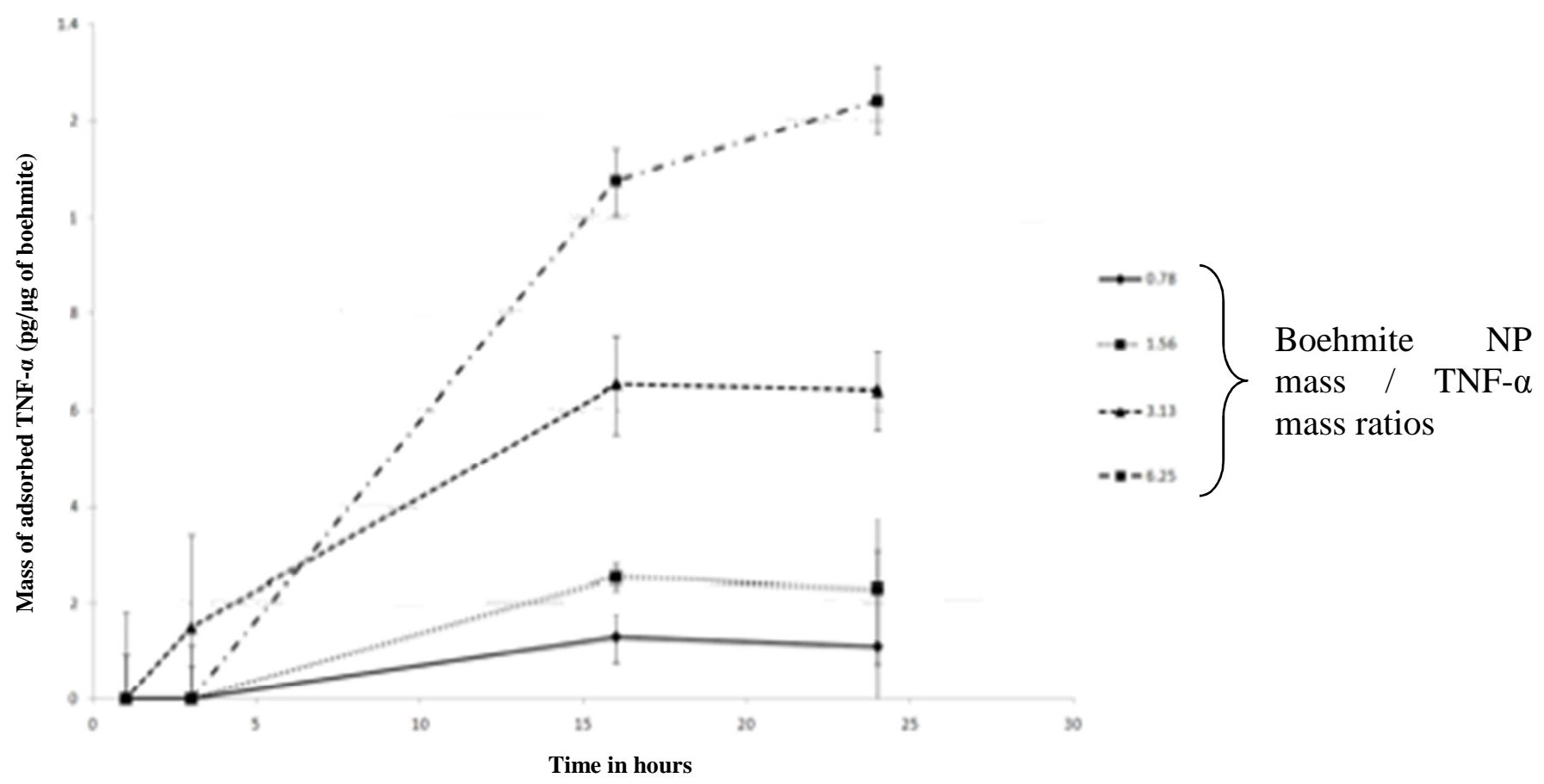


Fig. 7. Corrective curve representing the adsorbed TNF- $\alpha$ depending on the residual TNF- $\alpha$ after $24 \mathrm{~h}$ of incubation.

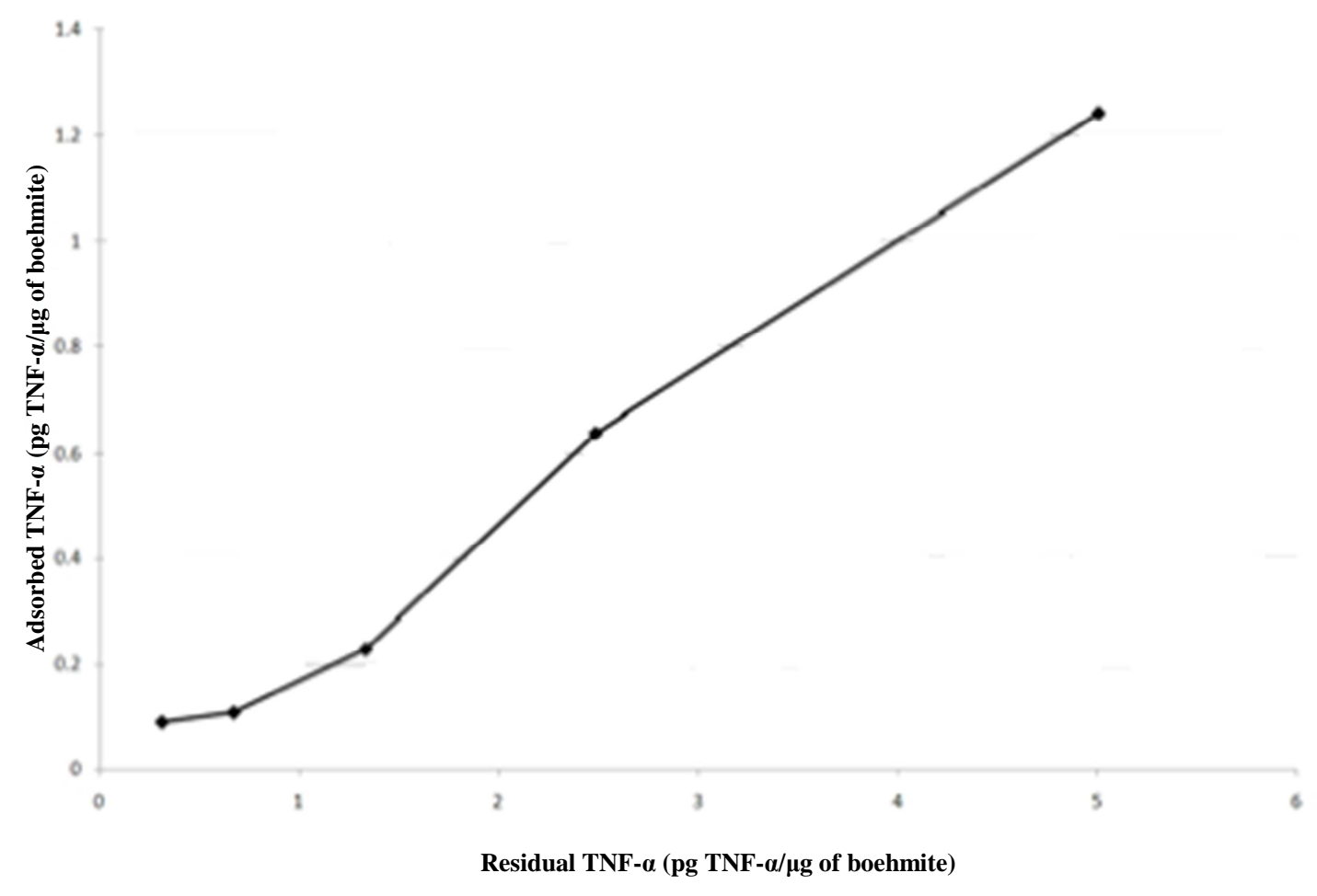

Fig. 8. Pro-inflammatory effect of boehmite NP as assessed by the TNF- $\alpha$ production $(\mathrm{pg} / \mathrm{ml})$ after correction of the adsorption and degradation artifacts. 


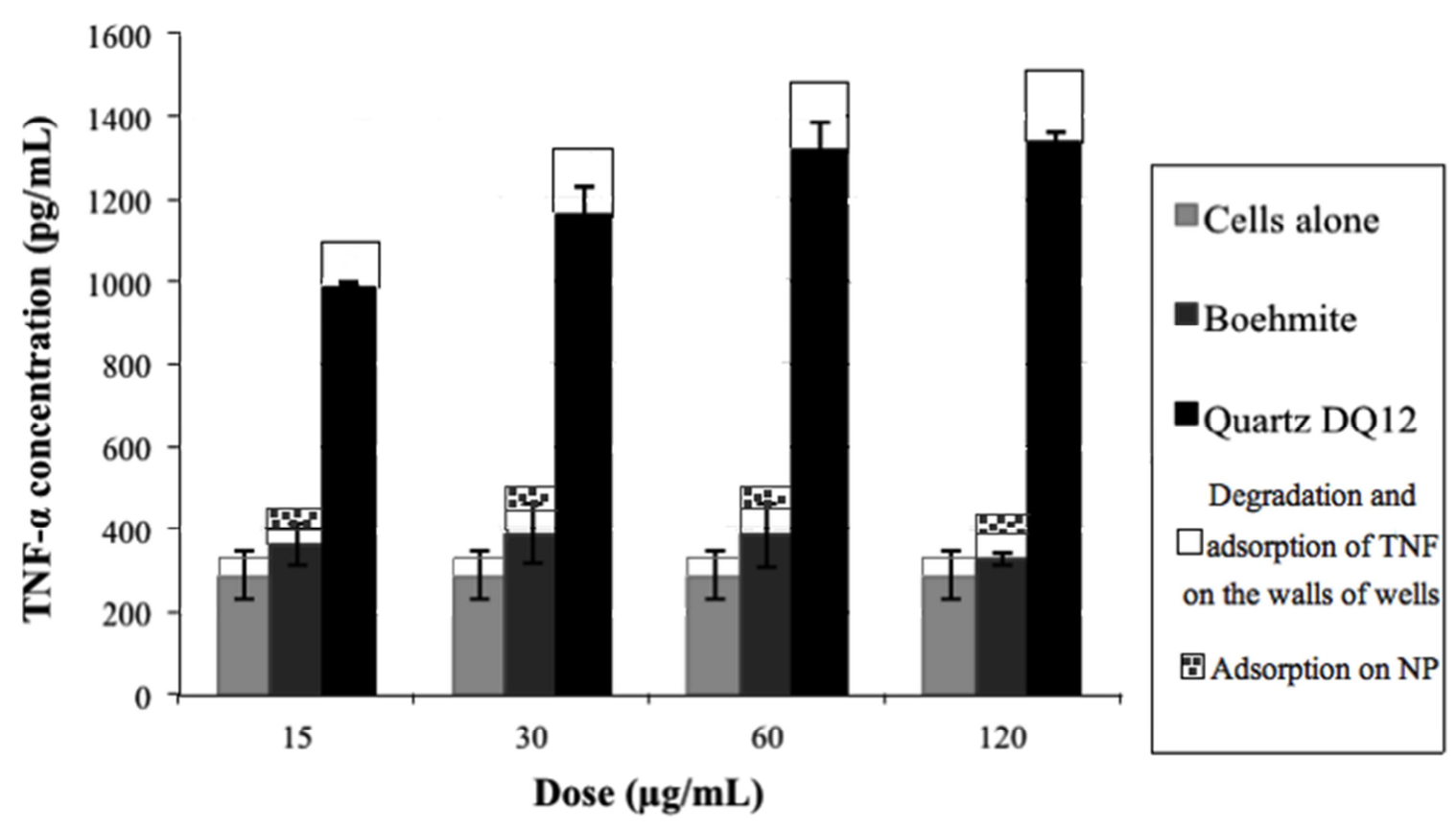

